\title{
Sosioestetik: Patung Ruang Publik Kawasan Hunian Masyarakat Urban
}

\author{
Gustiyan Rachmadi, Gustami,S.P., Suwastiwi Triatmodjo \\ Institut Seni Indonesia (ISI) Yogyakarta \\ Jl. Parangtritis Km. 6,5 Yogyakarta, 371233
}

\begin{abstract}
The main problem of this research is how the public space statue in urban areas can have an aesthetic meaning that focusing the harmony on the social, pragmatic, economic, education and recreation. So that the public space statues have integrative functions for the developers of property business and its users. This study was the creation of art works, offers an alternative concept in reconstructing the meaning of public space statue based on the beauty of the social environment in urban residential areas. The presence of a concept does not stop only at understanding the beauty visually but also aesthetic socially. This research aims to find and produce the creative process models of public space statue which are reliable, comprehensive and holistic in accordance with its text and context. Socio-aesthetic method has several stages: (1) Exploration (2) Experimentation and Improvisation, (3) Illumination, (4) Presentation and (5) Evaluation. Which includes in it: idea, peruses the creation and form of presentation. The idea and concept that have been reduced from the accompanied events poured in the visual process and represented in the form of public space statue in the housing complex of SSP Bandung. Construction of the creative process of creating a public space statue is expected to represent as one of application model of social-aesthetic.
\end{abstract}

Keywords: socio-aesthetic, public spaces statue,residential areas, urban society

\begin{abstract}
ABSTRAK
Permasalah pokok penelitian ini, bagaimana patung ruang publik di kawasan masyarakat urban dapat bermakna secara estetik dengan memperhatikan aspek harmoni secara sosial, pragmatis, ekonomis, edukasi dan rekreasi. Sehingga patung ruang publik ini memiliki fungsi integratif bagi pengembang dunia usaha property maupun masyarakat penggunanya. Penelitian penciptaan karya seni ini, menawarkan konsep pengembangan dalam merekonstruksi pemaknaan patung ruang publik yang berbasis pada keindahan lingkungan sosial kawasan hunian masyarakat urban. Kehadiran konsep yang tidak berhenti pada pemahaman keindahan secara visual saja, melainkan estetis secara sosial. Penelitian ini bertujuan menemukan dan menghasilkan model proses kreatif penciptaan karya seni patung ruang publik yang reliable, komprehensif dan holistik sesuai dengan teks dan konteksnya. Metode kajian Sosioestetik ini melalui beberapa tahapan: (1) Eksplorasi (2) Eksperimentasi dan Improvisasi, (3) Iluminasi, (4) Presentasi dan (5) Evaluasi. Yang mencakup di dalamnya: ide, peroses penciptaan dan bentuk penyajian. Gagasan serta konsep yang direduksi dari peristiwa pendukung yang menyertai, dituangkan dalam proses visual dan direpresentasikan dalam bentuk patung ruang publik di kawasan komplek perumahan SSP Bandung. Konstruksi proses kreatif penciptaan seni patung ruang publik ini diharapkan dapat mewakili sebagai salah satu model aplikasi esetika-sosial.
\end{abstract}

Kata kunci: sosioestetik, patung ruang publik, kawasan hunian, masyarakat urban 


\section{PENDAHULUAN}

Di Indonesia penempatan patung sebagai bagian dari ruang publik sudah dimulai sejak masa pemerintahan Orde Lama, yang menempatkan patung di beberapa titik ibu kota Jakarta. Pada masa pemerintahan Orde Baru hal tersebut terus berlanjut, hingga masa pasca Orde Baru, sedangkan pada masa reformasi pembuatan patung ruang publik yang dilakukan oleh pemerintah dapat dikatakan berkurang, walaupun ada, tidak sebanyak dibandingkan pada masa sebelumnya. Berbeda pada masa sekarang pembuatan patung ruang publik banyak dilakukan oleh pihak swasta. Hal ini dapat dilihat dengan dibangunya beberapa karya patung ruang publik oleh pihak swasta di beberapa kota besar di Indonesia seperti Jakarta, Bandung, Menado dan kota besar lainya.

Di era Orde Lama sebagian besar patung ditempatkan terfokus di wilayah ibu kota, khususnya di simpang jalan, sudutsudut kota, dan tempat strategis lainnya. Dewasa ini karya seni patung dengan berbagai bentuk dan gayanya tidak hanya dibangun di ibu kota atau pusat keramaian kota, seperti alun-alun atau persimpangan jalan saja, tetapi telah menyebar penempatannya di berbagai ruang-ruang kota hingga ke kawasan komplek perumahan.

Mencermati akan hal tersebut di atas, bahwa pemaknaan ruang sosial telah mendekati dan bersinggungan dengan dimensi yang berkaitan dengan ekonomi. Artinya kehadiran karya seni patung tidak hanya sebagai simbol patriotisme dan nasionalisme seperti pada masa Orde Lama dan Orde baru, melainkan merambah pada pencitraan sosial dan ekonomi, seperti karya seni patung yang berada pada suatu kawasan perumahan tertentu.

Secara diakronik, berdasarkan pada analisis data lapangan yang telah dilakukan, bahwa persoalan karya seni patung yang telah mengisi dan menghiasi di berbagai ruang eksterior dari arsitektur gedung, serta ruang publik di berbagai wilayah atau daerah kota-kota tertentu, khususnya dalam konteks periodisasi seperti disebutkan di awal telah membawa perubahan. Perubahan dimaksud, baik terkait dengan perubahan bentuk maupun gaya, demikian pula pada sisi makna dan fungsi secara sosial. Artinya hal ini dapat diasumsikan bahwa persoalan wujud, bentuk secara fisik tidak terlepas dengan persoalan-persoalan yang terkait, di antaranya adalah hubungan di antara keduanya dengan kehidupan sosial-budaya masyarakat lingkungan sekitar. Secara sinkronik, peristiwa-peristiwa ketidaksepahaman dan ketidakrelevanan mengenai nilai dan bentuk dari wujud patung itu sendiri masih sering dijumpai, seperti peristiwa protes warga serta penghancuran sepihak dari kelompok masyarakat tertentu. Hal ini terjadi pada Patung 'Tiga Dara' yang dibongkar masyarakat di Kota Bekasi, patung 'Tari Zapin' di Pekan Baru, dan patung 'Gatot Kaca' di Purwakarta Jawa Barat.

Peristiwa atau persoalan tersebut di atas menggugah dan menginspirasi ide gagasan untuk mengkaji lebih dalam mengenai seni patung itu sendiri, relevansinya dengan fasilitas zaman di tengah-tengah era kehidupan sosial-budaya dewasa ini. Peristiwaperistiwa itu dijadikan sebagai landasan pokok yang melatar belakangi gagasan dan konsep penciptaan karya tulis ini, khususnya dalam pengembangan kreativitas seni patung pada sebuah ruang publik di kawasan komplek perumahan.

Di era industrialisasi dan ekonomi sekarang ini, representasi ruang publik wilayah perkotaan khususnya dalam ranah realitas keindahan lingkungan yang harmonis, kini menjadi bertambah miskin dan berkurang. Secara fisik, ruang-ruang publik semakin sempit dan kurang diperhatikan. Asumsinya tidak hanya berkurang pada ranah 
pemanfaatan dan pemaknaannya, tetapi ruang publik telah mengalami pergeseran dan perkembangan dari fungsi sosial dan ekologis ke arah yang lebih praktis, yakni lebih mengarah pada daya guna sosialestetis (simbolis) dan ekonomis. Persoalan estetika yang bersifat simbolistik dan ikonis, khususnya dalam konteks patung yang mengisi atau menghiasi ruang publik, perlu dipertanyakan kembali terkait dengan pemahamannya tentang realitas estetik yang dilakukan melalui instrumeninstrumen yang proporsional, realistik, kontekstual, sinergi, dan harmoni untuk diungkapkan sebagai tindakan nyata dari pengembangan kreativitas seni patung pada suatu ruang publik.

Sebagai model kreativitas dalam penggarapan disertasi penciptaan karya seni patung ruang publik ini adalah bagaimana mengolah ruang publik di kawasan komplek perumahan dapat diwujudkan menjadi karya seni yang memiliki makna sosial-estetik bagi masyarakat penggunanya, baik secara langsung maupun tidak langsung, karya seni tidak hanya sebatas indah dinikmati dari satu aspek pandang saja. Dengan demikian rumusan masalah dalam bentuk pertanyaan riset, pertama, mengapa karya seni patung perlu dihadirkan di kawasan perumahan masyarakat urban? Kedua, unsur-unsur apa saja yang memandu perwujudan karya patung ruang publik yang relevan dan ideal, baik secara bentuk, nilai dan makna, maupun kaitannya dengan pencitraan kawasan pemukiman masyarakat urban? Ketiga, bagaimana menciptakan bentuk visual patung ruang publik di kawasan perumahan perkotaan, yang relevan dengan nilai dan makna dari lingkungan masyarakat setempat.

Berangkat dari dorongan peristiwa seperti disebutkan pada latar belakang di atas, bahwa tujuan penciptaan ini adalah merekonstruksi pemaknaan patung ruang publikyang berbasis pada lingkungan sosial kawasan hunian masyarakat urban, sehingga patung tidak berhenti pada pemahaman keindahan secara visual saja, melainkan estetis secara sosial. Gagasan serta konsep yang direduksi dari peristiwa seperti pada latar belakang tersebut di atas, kemudian dituangkan dalam proses visualisasi dan direpresentasikan dalam bentuk patung ruang publik di kawasan komplek perumahan SSP Bandung, diharapkan dapat mewakili sebagai salah satu model aplikasi esetika-sosial. Secara khusus tujuan penelitian karya cipta seni ini adalah pertama, mensinergikan nilai dan fungsi keindahan visual dengan nilai-nilai sosial dalam suatu tatanan lingkungan kawasan perumahan masyarakat kota. Kedua, mewujudkan harmonisasi keindahan ruang publik kawasan perumahan masyarakat kota secara proporsional khususnya kawasan SSP Cisarua Bandung yang bernuansa sosial.

Patung dengan berbagai bentuk dan gayanya telah mengisi ruang-ruang publik khususnya di daerah ibu kota Jakarta dan kota-kota besar, seperti di Bandung, Surabaya, Semarang, Yogyakarta dan lain sebagainya. Namun demikian apakah perwujudan dari seni patung ruang publik tersebut sudah sesuai dengan lingkungannya atau hanya bersifat dan bermakna menghias terhadap fasilitas fisik suatu ruang tertentu. Kalau memang hanya pada tataran seperti itu, berarti karya seni patung ruang publik itu secara fisik berjarak dari persoalan interaksi sosial masyarakatnya. Padahal dapat dirasakan manfaat dan kegunaan dari ruang publik itu sendiri, adanya interaksi sosial yang sangat dekat dan erat sekali.

Dari sisi lain, karya seni patung ruang publik ini dengan berbagai bentuk modelnya, yakni figuratif (personal, allegorical form, portait statue) maupun non-figuratif (impersonal, abstract), secara visual telah berhasil memberikan daya rangsang yang dapat mengalihkan perhatian publik sekaligus 
mengubah citra ruang menjadi indah dan menawan. Sebaliknya ada beberapa karya patung yang tidak berhasil seperti itu, contohnya karya patung 'Tiga Dara' di Bekasi dan patung 'Gatot Kaca' di Purwakarta Jawa Barat yang diprotes dan dibongkar oleh sekelompok masa karena diindikasikan tampilan visualnya tidak selaras dengan ideologi masyarakat sekitarnya.

\section{METODE}

Penelitian ini merupakan penelitian kualitatif penciptaan seni melalui metode pendekatan rekonstruksi proses kreatif dengan strategi ekspreimentatif. Proses penelitian penciptaan ini dengan memperhatikan dan mempertimbangan beberapa aspek pendukung proses penciptaan patung ruang publik sebagai salah satu model pengembangan keilmuan interdisiplin seni dan sosial (sosioestetik).

\section{a. Tahap Identifikasi}

Gambaran wujud patung ruang publik pada disertasi penciptaan ini menekankan pada esensi keindahan yang bermuatan nilai dan makna sosial. Artinya, patung sebagai teks (keindahan visual), aplikasinya dalam ruang publik memiliki keterhubungan yang relevan yakni pada konteks sosial (rekreasiedukasi).

Karya patung ruang publik di perumahan tidak berjarak dengan masyarakat lingkungan sekitar. Masyarakat dapat berinteraksi langsung dengan karya seni tersebut.

Patung ruang publik dibuat dengan memperhatikan:

- luas area, denah lokasi, dan sirkulasi, dengan memperhatikan hal tersebut dapat digambarkan ukuran besar patung, tinggi patung dan elemen penunjangnya.

- Kultur masyarakat, dengan memperhatikan kultur masyarakat penghuni dan kondisi lingkungan masyarakat seki- tarnya, baik pada aspek ideologi, pendidikan, historis dan lain sebagainya nantinya akan dapat digambarkan melalui gaya visual dari patung dimaksud.

- Memperhatikan historis dari daerah setempat, nantinya akan dapat digambarkan melalui bentuk patung.

- Memperhatikan gaya arsitektur komplek perumahan "SSP Bandung" yang moderen. Patung akan menselaraskan pada gaya arsitektur tersebut, selengkapnya lihat tabel 1.

\section{b. Tahap Eksplorasi}

Berdasarkan pengamatan dan analisis awal terhadap latar belakang dan tinjauan referensi tersebut di atas, ditemukan beberapa unsur yang mempengaruhi terhadap proses perwujudan atau penciptaan karya. Pada tahap eksplorasi, yakni pra-image atau sering disebut proses pengembaraan kognitif dari pengalaman-pengalaman atau peristiwa yang pernah di alami oleh seseorang, pada ranah ini, unsur-unsur seperti yang terdapat di dalam peristiwa, gagasan dan pengalaman dapat dikelompokan:1) unsuryang mempengaruhi kegelisahan seniman, 2) lingkungan alam, 3) lingkungan sosial-budaya, 4) material yang terkait dengan persoalan-persoalan terhadap kesesuaian bentuk dan fungsi, baik secara praktis maupun secara sosial dan interaksinya.

Unsur yang mempengaruhi kegelisahan seniman baik secara internal maupun eksternal. Secara internal yaitu diri pengalamanpengalaman pengetahuan mematung penulis selama menggeluti profesi seniman seni patung dari masa pertama kuliah S1 hingga masa sekarang. Secara eksternal, yaitu pengalaman diri penulis sewaktu masih kanakkanak, yang dalam hal ini berposisi sebagai pengguna fasilitas zaman seperti anak-anak lain pada umumnya, yaitu anak yang aktif cenderung suka bermain di lingkungan pelataran/halaman rumah, lapangan, dan atau area fasilitas umum lainnya. 
Tabel 1 Unsur-unsur pemandu penciptaan patung ruang publik di Komplek Perumahan SSP Bandung

\begin{tabular}{|c|c|c|c|}
\hline No. & $\begin{array}{c}\text { Sub Bidang } \\
\text { Terkait }\end{array}$ & Unsur Pengaruh & $\begin{array}{l}\text { Unsur Pertimbangan } \\
\text { (Sosio-estetik) }\end{array}$ \\
\hline 1 & Ekologi & $\begin{array}{l}\text { - Struktur alam dan lingkungan } \\
\text { - Cuaca } \\
\text { - Perkebunan, tanah gembur } \\
\text { (dataran tinggi) }\end{array}$ & Konstruksi dan material bahan patung \\
\hline 2 & Geografi & $\begin{array}{l}\text { - Daerah/wilayah pengembangan kota } \\
\text { (Bandung Barat) }\end{array}$ & Lingkungan masyarakat pekerja/pegawai \\
\hline 3 & $\begin{array}{l}\text { Kepen- } \\
\text { dudukan } \\
\text { Masyarakat } \\
\text { Penghuni }\end{array}$ & $\begin{array}{l}\text { - Sebagian besar penghuni kelompok } \\
\text { keluarga muda, profesi pegawai negeri } \\
\text { dan swasta. } \\
\text { - Rata-rata memiliki anak usia } 3 \text { tahun } \\
\text { s.d } 8 \text { tahun dengan jumlah } 30 \text { anak. } \\
\text { - Jumlah KK 73, dari } 85 \text { rumah yang } \\
\text { tersedia. }\end{array}$ & $\begin{array}{l}\text { Kebutuhan bagi anak-anak penghuni } \\
\text { terkait dengan area atau lahan ruang publik } \\
\text { taman komplek perumahan "SSP Ban- } \\
\text { dung" }\end{array}$ \\
\hline 4 & $\begin{array}{l}\text { Kondisi } \\
\text { Sosial-Eko- } \\
\text { nomi }\end{array}$ & $\begin{array}{l}\text { - Sistem budaya setempat } \\
\text { - Strata sosial dan ekonomi masyarakat } \\
\text { setempat. } \\
\text { - Gaya hidup }\end{array}$ & $\begin{array}{l}\text { Masyarakat urban dari berbagai daerah, } \\
\text { suku, etnis yang bermukim sebagai ang- } \\
\text { gota masyarakat pekerja/pegawai (tingkat } \\
\text { kesibukan tinggi) }\end{array}$ \\
\hline 5 & $\begin{array}{l}\text { Kondisi } \\
\text { Kultural dan } \\
\text { Religi }\end{array}$ & $\begin{array}{l}\text { - Sistem kepercayaan dan keyakinan } \\
\text { warga masyarakat penghuni. } \\
\text { - Ideologi budaya }\end{array}$ & $\begin{array}{l}\text { - Mayoritas beragama Islam } \\
\text { - Modern, demokratis, adaptif, dan terbuka }\end{array}$ \\
\hline 6 & $\begin{array}{l}\text { Lingkungan } \\
\text { Arsitektur } \\
\text { kawasan } \\
\text { pemukiman }\end{array}$ & $\begin{array}{l}\text { - Gaya arsitektur } \\
\text { - Pencitraan }\end{array}$ & Modern, Pragmatis, minimalis \\
\hline 7 & Historis & $\begin{array}{l}\text { Beberapa informasi yang didapatkan } \\
\text { pada masa sebelum dibangun kawasan } \\
\text { perumahan di daerah SSP Bandung dan } \\
\text { sekitarnya (Cisarua Bandung Barat) }\end{array}$ & $\begin{array}{l}\text { Kawasan sebelumnya adalah kawasan } \\
\text { perkebunan/perbukitan yang memiliki } \\
\text { banyak pepohonan rindang dan dihuni } \\
\text { banyak burung. }\end{array}$ \\
\hline 8 & $\begin{array}{l}\text { Managemen } \\
\text { Seni Rupa } \\
\text { (Patung) } \\
\text { aplikasinya } \\
\text { dalam bi- } \\
\text { dang usaha } \\
\text { property }\end{array}$ & $\begin{array}{l}\text { Berfokus pada kepentingan pembuat, } \\
\text { pengguna, dan pemesan secara utuh } \\
\text { dan harmoni }\end{array}$ & $\begin{array}{l}\text { - Kepentingan pembuat: idealisme aka } \\
\text { demik. } \\
\text { - Kep. pengguna: patung yang indah ber } \\
\text { makna luas (substantive) } \\
\text { - Kep. pemesan: saling menguntungkan }\end{array}$ \\
\hline
\end{tabular}

Kegelisahaan pada perkembangan kota yang cenderung seiring berbalik dengan pengembangan atau pemeliharaan ruangruang publik yang kian menyempit sebagai fasilitas umum yang jarang didapatkan di lingkungan kota-kota besar seperti Bandung.

Unsur-unsur lingkunganalam yang dapat mempengaruhi wujud dan bentuk karya itu sendiri. Hal ini juga sangat ditentukan oleh pengetahuan dan kreativitas seniman. Alam dan lingkungannya adalah sumber inspirasi yang paling kaya akan referensi-referensi bentuk, material dan teknik yang dapat diadopsi pada kreativitas seni patung pada khususnya.
Unsur-unsur lingkungan sosial-budaya yang mencakup historikal lingkungan kawasan tersebut, ideologi dan keyakinan masyarakat pengguna dan sekitar, serta status sosial khusunya ilmu pengetahuan dan ekonomi.

Unsur-unsur material yang terkait dengan persoalan kesesesuaian bentuk, teknik pengerjaan dan fungsi baik secara praksis maupun secara simbolis (pencitraan dan keindahan).

Dengan memperhatikan peristiwa yang telah dipaparkan pada latar pada latar belakang di atas, serta kaitannya dengan poin di atas, realitasnya ada beberapa kepentingan yang mempengaruhi terhadap per- 


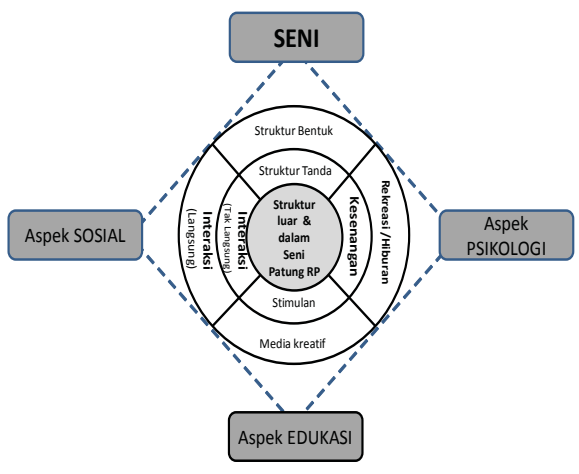

Bagan 1: Aspek Pertimbangan Penciptaan Beberapa aspek interdisipliner yang terkait dengan unsur pemandu perwujudan patung ruang publik di Kawasan Pemukiman Masyarakat Urban "SSP Bandung”. (Sumber: Bagan diadaptasi dari Tjetjep Rohendi Rohidi, 2011)

soalan-persoalan ruang publik di lingkungan masyarakat kota. Pengaruh dan dominasi aktivitas tersebut dapat digambarkan pada bagan 1 .

\section{HASIL DAN PEMBAHASAN}

\section{Tinjauan Tentang Ruang dan Ruang Publik}

Kata ruang publik merupakan terjemahan dari kata public space dalam bahasa Inggris. Anehnya kata tersebut tidak memiliki penjelasan semantik untuk menjelaskan dirinya sendiri. Jalan yang terbaik untuk menangkap artinya adalah dengan cara melacak padanan katanya. Dalam Webster's New World College Dictionary of Current English (1995:1087) dikutip Miky E. Santoso (2006:99-105), ada satu kata yang sepadan dengan kata public space, yaitu kata public domain, yang berarti: 1) public land; 2) the conditions of being free from copyright or patent and hence, open to use by anyone. Menurut Miky E. Santoso (2006:99-105), tempat (place) merupakan bagian dari ruang (space) yang didiami dan digunakan oleh seseorang atau sesuatu, dan memberikan pemaknaan (meaning) dan nilai (value) pada ruang tersebut. Tempat adalah ruang interaksi masyarakat dengan lingkungan di dekatnya yang memberikan karakteristik pada tempat tersebut sehingga berbeda dengan lingkungan sekitar yang lain. Bertolak dari kedua pengertian tersebut nampak bahwa masyarakat Komplek Perumahan SSP Bandung memiliki peranan yang besar dalam memberikan permaknaan terhadap ruang yang ada di dalam lingkungan komplek perumahan tersebut. Karena ruang di sekitarnya sering digunakan dan mudah diakses oleh publik, maka ruang di sekitar ruang terbuka hijau itu disebut sebagai ruang publik.

Terkait dengan keberadaan ruang publik dan pemahamannya terhadap kehidupan publik di dalamnya, serta pemahaman historis terhadap perkembangan ruang terbukanya, ruang publik perlu mempunyai setidaknya tiga pola perilaku (behavioural setting), yaitu: responsif, demokratis dan bermakna. Responsif meliputi aspek kenyamanan, tempat berekreasi, tempat mengadakan pertemuan, tempat mengadakan hubungan atau komunikasi dan berdiskusi, baik aktif maupun pasif, serta sebagai tempat untuk beristirahat, melepaskan lelah dari kehidupan rutin. Pola responsif ini dirancang dan dikelola untuk melayani kebutuhan pemakainya. Demokratis dalam arti dapat diakses oleh seluruh publik atau masyarakat dan memberikan kebebasan untuk beraktivitas serta dapat melindungi hak-hak penggunanya. Bermakna, yaitu mempunyai ikatan yang erat dengan tempat atau kondisi sekitarnya, terutama kehidupan masyarakatnya dalam konteks yang lebih luas dan mereka terkait dengan lingkungan secara fisik maupun sosial. Keterikatan tersebut berhubungan dengan aspek-aspek yang melatarinya, serta dapat memberikan kesempatan kepada orang atau masyarakat untuk memahami keterkaitan yang kuat antara tempat, kehidupan pribadinya, dan dunia yang luas (Santoso, 2006:100-101).

Ruang publik dan ruang privat secara 
fenomenologis tidak dapat dipisahkan satu dengan yang lain. Seorang subjek merasakan kehadirannya secara bersamaan, sama dengan fenomena ketika ia merasakan dualitas batas dan ruang serta isi dan kosong sekaligus (Pierre Albert Birot,1995:217). Makna yang satu senantiasa tergantung kepada yang lain. Demikianlah hubungan antara ruang pribadi dan ruang publik. Ruang publik dan ruang privat bukan dua hal yang terpisah secara mutlak, meskipun jelas berbeda, karena masing-masing memiliki struktur, baik fisik maupun makna serta aturannya sendiri. Pada saat membawa ruang privat ke dalam ruang publik, orang senantiasa sadar bahwa dia harus membatasi atau menyesuaikannya dengan sifat ruang publik yang dimasukinya. Ruang publik dalam arti yang sungguh-sungguh murni adalah ruang yang memang tidak boleh dikuasai oleh pihak atau kelompok tertentu.

\section{Sosioestetik Patung Ruang Publik}

Secara tekstual, estimasi karya ini didasari dari hasil analisa patung-patung ruang publik di Indonesia dari periode masa Orde Lama, Orde Baru dan Orde Reformasi. Secara kontekstual, terinspirasi dari bebe-rapa unsur pertimbangan seperti pada tabel 1, seperti di antaranya, patung ruang publik ini mengelaborasi kebutuhan sosial masyarakat penghuninya dengan orientasi pada fungsi rekreasi dan edukasi.

Berdasarkan hasil analisa problematika patung ruang publik pada tahapan no 3 bagan 2, khususnya studi terhadap posisi dan penyebaran patung pada masa Era Reformasi ditemukan beberapa bentuk patung ruang publik yang ada di kawasan perumahan masyarakat kota. Dari hasil observasi studi lapangan di kawasan "SSP Bandung" dan komparasi karya-karya patung sejenis terdahulu di beberapa daerah lainnya, gambaran wujud patung ruang publik pada karya tulis penciptaan ini menekankan pada esensi

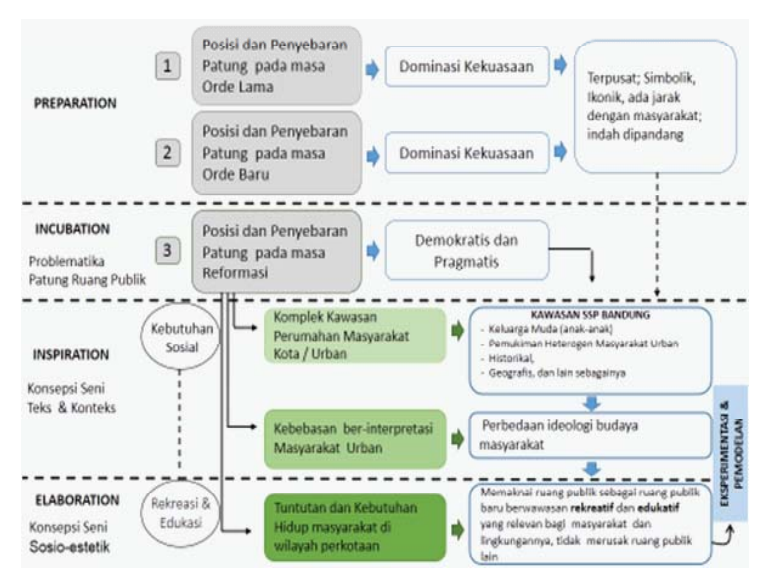

Bagan 2: Skema Jalan Pengembangan Konsep Penciptaan Patung Ruang Bublik di SSP Bandung (Bagan alur berfikir ini dibuat Penulis)

keindahan yang bermuatan nilai dan makna sosial. Artinya, patung sebagai teks keindahan visual, aplikasinya dalam ruang publik memiliki keterhubungan yang relevan dan kotekstual. Relevansi keterhubungan patung sebagai elemen estetis di lingkungan sosial perumahan (dunia property) secara kontekstual dan penciptaannya perlu memperhatikan unsur-unsur yang mempengaruhi pada proses pembuatannya. Adapun indikator yang menjadi unsur-unsur pertimbangan dalam perancangan konsep bentuk patung ruang publik ini adalah sebagai berikut.

Unsur-unsur pemandu tersebut di atas, secara interdisiplin keindahan seni patung harus dirangkum dalam suatu pertimbangan secara holistik menjadi tema dan konsep penciptaan patung ruang publik yang proporsional dan harmoni di antara berbagai kepentingan dan dominasinya.

Secara administratif dan manajerial pada penciptaan karya seni patung ruang publik ini direncanakan akan mengikuti dan menyesuaikan waktu yang sudah ditentukan oleh Pascasarjana Institut Seni Indonesia Yogyakarta, mulai dari ujian proposal, penulisan, penciptaan sampai ke ujian dan pameran. Dalam penciptaan ini diadakan peninjauan dan pengamatan terhadap tempat atau lokasi dan objek kajian, serta memper- 
hatikan dan mempertimbangkan beberapa aspek, seperti lokasi komplek perumahan (luas dan kulturnya), dan gaya arsitektur komplek perumahan "SSP Bandung"

Sebagai gambara wujud, digambarkan lokasi dan kondisi komplek perumahan sebagai berikut:

- Luas area, dengan memperhatikan denah lokasi dapat digambarkan ukuran besar patung, tinggi patung dan elemen penunjangnya.

- Kultur masyarakat, dengan memperhatikan kultur masyarakat penghuni dan kondisi lingkungan masyarakat sekitarnya, baik pada aspek ideologi, pendidikan, dan lain sebagainya nantinya akan dapat digambarkan melalui bentuk, material bahan dan gaya visual dari patung dimaksud.

Sebelum patung dibuat dan ditempatkan pada area ruang publik yang ditentukan, beberapa alternatif bentuk patung direncanakan akan dibuat dalam skala 1 : 10, dengan pendekatan material yang sama dengan skala 1:1. Dari beberapa alternatif patung tersebut, akan dipilih salah satu untuk direalisasikan dengan skala 1:1 yang akan ditempatkan di ruang publik di lingkungan perumahan SSP di Bandung.

\section{Karya Seni Patung: Ruang Fisik dan Ruang Sosial}

Merujuk pada teori Feldman dalam Art as Imange and Idea, karya patung yang berada di ruang publik termasuk dalam karya seni yang mempunyai fungsi sosial dimana ia dibuat untuk kepentingan umum. Pada karya patung berfungsi sosial, seorang seniman berkarya bukan untuk dirinya sendiri, tetapi sebagai tanggapan terhadap keadaan sosialnya. Untuk itu seniman harus dapat mengutarakan tanggapannya melalui karya dengan beberapa unsur pertimbangan, dengan satu tujuan agar dapat dimengerti oleh semua lapisan masyarakat. Mengenai batasan fungsi sosial seni, Feldman menyatakan bahwa seni dapat termasuk ke dalam fungsi sosial,:

“(1) It seeks or tends to influence the collective behavior of people, (2) It is created to be seen or used primarily in public situations; and (3) it expresses or descibes social or collective aspects of existence as opposed to individual and personal kinds of experience" (Feldman, 1967:36).

Oleh karena itu patung yang ditempatkan di ruang publik secara tidak langsung dapat mempengaruhi nilai dan manfaat lingkungannya, baik dalam lingkup arsitektural maupun dalam lingkup sosial, yang pada akhirnya menciptakan sebuah lingkungan yang lebih baik.

Ruang Sosial menurut Ridwan Kamil (2002) dalam artikelnya "Arsitektur Kota Anti Kota" dalam majalah I-Arch, edisi 02/2002, bahwa the city is the people. Ia mencontohkan bahwa kota-kota dunia yang masuk kategori world great cities umumnya memiliki kepedulian atas pentingnya ruang sosial kota, social space sebagai bagian dari roh kehidupan sebuah kota. Menurutnya, kemajuan peradaban, teknologi, dan kompleksitas budaya tidak seharusnya merusak pemahaman bahwa kota adalah untuk kehidupan manusia itu sediri. Ia berpendapat bahwa bangunan hadir dan bersentuhan dengan publik, sehingga sudah semestinya bahwa setiap gedung yang dirancang dalam kota urban haruslah menjadi karya arsitektur yang memiliki kepeberpihakan terhadap sistem ekologis yang sensitif menghidupkan lingkungan kota dengan berbagai alternatif fasilitasnya. Dalam konteks ini nampak bahwa pada akhirnya keberadaan sebuah patung di ruang publik, kembali kepada otoritas penggunanya, yakni publik atau masyarakat yang ada di sekitarnya. Faktor hasrat dan emosi, latar belakang pengalaman, berbagai kepentingan dan juga peran serta ekonomi kapitalis sebagai sistem global juga ikut mempengaruhi pola perilaku, aktivitas dan pemahaman publik atas patung di ruang publik. 
Dalam buku Indonesian Heritage, "Visual Art" Seri Ke 7, dikatakan bahwa setelah Indonesia merdeka, pemerintahan pertama dipimpin oleh Presiden Soekarno yang merupakan seorang arsitek terdidik dan pecinta seni yang pada era ini memulai sebuah program perencanaan dan pengembangan kota di Indonesia, terutama Ibukota Jakarta yang menjadi pintu gerbang negara. Salah satu gedung pertama di Jakarta adalah Hotel Indonesia yang dibangun pada tahun 1962 oleh arsitek Amerika, Sorensen. Presiden Soekarno bersemangat untuk membangun hotel ini sebagai sebuah bagian percontohan negara. Dengan pikiran ini, ia memanggil para seniman dari Yogyakarta ke Istana Presiden di Bogor untuk membicarakan perihal gagasannya. Tim ini terdiri dari: Hendra Gunawan, Sudarso, Djoni Trisno, Sutopo, Haryadi, Gambir Anom, Surono, Edhi Sunarso, dan G. Sidharta Soegijo. Presiden kemudian memesan relief, lukisan dinding, dan patung untuk menghias gedung dan menekankan bahwa hotel harus menjadi kebanggaan bangsa. Soekarno lebih jauh menentukan bahwa semua seni harus dihasilkan oleh para seniman Indonesia menggunakan bahan-bahan setempat. Peristiwa tersebut merupakan awal seni untuk umum di Indonesia dan tentu diharapkan dapat diapresiasi oleh masyarakat (Tjahjono, 2002). Dalam hal ini, apresiasi dapat diartikan mendapat tanggapan dari masyarakat, sehingga mereka dapat mengerti nilai-nilai yang disampaikan, atau menolak, atau dapat menikmati karya tersebut sebagai wujud keindahan suatu benda sebagai unsur rupa saja, juga tentang keberadaannya di tempat umum atau ruang publik.

\section{Tinjauan Aspek Edukasi dan Rekreasi bagi anak dan orang dewasa}

Dengan memperhatikan beberapa bidang dan unsur yang terkait dan terdapat di dalam proses penciptaan karya seni patung

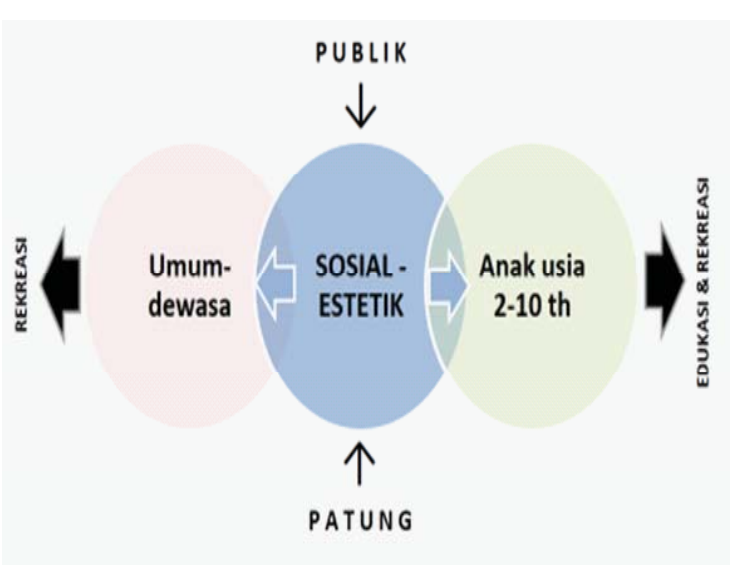

Bagan 3: Kerangka Teoritikal yang menuntun pada Konsep Bentuk

ruang publik ini, maka konsep bentuk patung ruang publik di SSP Bandung adalah relevansinya dengan sosial estetik. Konsep sosial estetik adalah usaha untuk menghadirkan aspek edukasi dan rekreasi pada patung ruang publik di SSP Bandung yang sesuai dengan konteksnya.

Teori rekreasi yang dikembagkan oleh Schaller dan Lazarus, dua orang sarjana Jerman di antara tahun 1841 dan 1884 menyatakan permainan itu sebagai kesibukan rekreatif, sebagai lawan KERJA dan keseriusan-hidup. Orang dewasa mencari kegiatan bermain-main, apabila ia merasa capai sesudah bekerja atau melakukan tugas-tugas tertentu. Dengan begitu permainan tadi bias "me-rekiir" kembali kesegaran tubuh yang tengah lelah (Kartono,1990:117).

Dengan jalan bermain-main, anak melakukan eksperiment tertentu, dan bereksplorasi, sambil mengetest kesanggupannya. Melalui permainan anak mendapatkan macam-macam pengalaman yang menyenangkan, sambil menggiatkan usaha belajar dan melaksanakan tugas-tugas perkembangan. Semua pengalamannya visa kegiatan bermain-main, anak memberikan dasar yang kokoh kuat bagi pencapaian macam-macam keterampilan yang sangat diperlukan bagi pemecahan kesulitan hidup di kemudian hariya (Kartono,1990:117). 
Dari pernyataan tersebut, dinyatakan secara tegas bahwa rekreasi mencakup pada kebutuhan orang dewasa juga pada anakanak. Bentuk kegiatan nyata dari rekrekasi itu adalah lawan dari kerja dan dan keseriusan dalam perilaku kehidupan. Demikian pula bahwa rekreasi dan edukasi memiliki hubungan yang sangat erat di dalam suatu bentuk konsep bermain. Karena di dalam bermain juga memuat aspek edukasi, demikian pula di dalam edukasi memuat rekreasi. Di dalam edukasi memuat rekreasi ditujukan pada bentuk atau model pengemasan edukasi itu sendiri, yakni pengemasan edukasi dengan konsep bermain sambil belajar, belajar melalui bentuk-bentuk dan atau metode bermain.

\section{PENUTUP}

Perlunya menghadirkan gagasan karya seni patung yang mempertimbangkan unsurunsur terkait sesuai dengan kondisi lingkungan alam, dan sosial masyarakat penghuni di kawasan perumahan masyarakat urban (SSP Bandung) dengan memperpadukan fungsi estetik dan fungsi sosial. Selain itu perlu merumuskan dan mewujudkan konsep dan bentuk patung ruang publik 'Sosioestetik' dengan berbagai unsur-unsur yang memandu perwujudan karya patung ruang publik yang relevan dan ideal, baik secara bentuk, nilai dan makna, bagi masyarakat (SSP Bandung, akademisi bidang keilmuan dan masyarakat luas).

Penciptaan Patung Ruang Puplik dalam konteks Sosio-estetik (1) memperhatikan aspek kontekstual masyarakat setempat; (2) memiliki citra kawasan; (3) berfungsi interaktif (tidak hanya indah dipandang mata/ berjarak); (4) terintegrasi dengan konsep perumahan yang memberikan ruang untuk berinteraksi antar penghuninya.

\section{Daftar Pustaka}

\section{Albert Birot, Pierre}

1995 Les Amusements Naturels Dikutip oleh Gaston Bachelard, dalam Poetics of Spaca.

Feldman, E.B

1967 Art as image and idea. New Jersey Prentice Hall.

Goenawan Tjahjono

2002 Indonesia Heritage, "Visual Art", Glorier, Jilid 7, Jakarta.

Husen Hendriyana

2008 “Tinjauan Kreativitas pada Proses Penciptaan Alat Musik karya Dodong Kodir", Panggung Jurnal Seni dan Budaya. Vol. 18, No.1.

Kartini Kartono

1990 Psikologi Anak (Psikologi Perkembangan). Jakarta: Penerbit Mandar Maju.

Tjetjep Rohendi Rohidi

2011 Metodologi Penelitian Seni. Semarang: Cipta Prima Nusantara.

Ridwan Kamil

2002 "Arsitektur Kota Anti Kota", I-Arch: Grasindo Mediatama, edisi 02, tahun 2002, Jakarta.

Santoso, M.E

2006 “Berbagai Konsep Pemikiran Berkaitan dengan Korelasi antara Monumen dan Ruang Publik di Sekitarnya", Jurnal Imaji FSRD U.K. Maranata, Bandung. 